\title{
Perancangan Sistem Informasi Inventaris Barang Berbasis Web
}

\author{
http://dx.doi.org/10.28932/jutisi.v7i2.3597
}

Riwayat Artikel

Received: 01 Mei 2021 | Final Revision: 25 Juni 2021 | Accepted: 29 Juni 2021

\author{
Antonius Oko Pranoto ${ }^{\bowtie \# 1}$, Eko Sediyono ${ }^{* 2}$ \\ \#*Jurusan Teknik Informatika, Universitas Kristen Satya Wacana \\ Jl. Dr. O. Notohamidjojo, Kel. Blotongan, Kec. Sidorejo, Salatiga \\ 1672017110 astudent.uksw. edu \\ ${ }^{2}$ eko@uksw. edu
}

\begin{abstract}
Information technology is rapidly developing and applied in any field of interest. It can be used as simple to the complex computation. It can also use greatly assisting human performance in managing inventory items. This paper discusses a website-based item inventory system applied in a very remote village in Desa Kusik Batu, West Kalimantan. The research goal is to facilitate the performance of village officials in managing data items, where overall data input is still done manually. The method of this research is using interviews, documentation, and literature studies. The implementation of the system resulted from this research is the following features: user data, all goods data having by the village, incoming goods data, outgoing goods data, avoid physical calculations, asset mutation reports, and goods reports, as well as making goods inventory reports can be easily done. With the existence of a web-based inventory information system website, at the village office of Kusik Batu Lapu, West Kalimantan, can improve the performance of village officials to manage goods data.
\end{abstract}

Keywords— Goods; Information systems; Inventory; Websites.

\section{Pendahuluan}

Teknologi informasi dapat diimplementasikan untuk berbagai kepentingan, baik yang teoritis maupun praktis, dari yang paling sederhana sampai ke sistem yang paling kompleks.Menurut Sudarsono (2015), perusahaan swasta nasional memanfaatkan teknologi informasi untuk mengelola aset perusahaan. Dengan menggunakan sistem informasi aset yang dibuat dapat digunakan untuk mendapatkan data aset baik keberadaannya maupun proses pemindahannya. Dengan adanya sistem informasi aset staf yang semula melakukannya secara manual, saat ini staf tersebut pekerjaannya makin dipermudah. Dengan adanya sistem informasi pengelolaan aset data dapat diolah secara akurat dan efisien, dan kinerja staff meningkat [1].

Selain pengelolaan dan pemanfaatan pencatatan data inventaris desa, Nastiti (2014), mengemukakan mengenai sarana dan prasarana inventaris barang di sekolah dasar harus bisa dikelola dengan baik. Dengan adanya sistem informasi, maka pengelolaan infrastruktur menjadi mudah, dan keberadaan sistem informasi ini menjadi salah satu penilaian sekolah dalam melakukan akreditasi [5].

Juliana (2017) mengemukakan, masalah yang sering terjadi di Perguruan Tinggi adalah pendataan masih secara konvensional. Hal ini menyebabkan pengulangan data, sehingga mengakibatkan pencatatan data barang tidak akurat dan tidak efisien. Dalam hal ini penyimpanan buku arsip di dalam lemari buku arsip juga mempengaruhi kesulitan dalam mencari data yang diperlukan setiap saat. Hal ini yang mendasari mengapa manajemen data berbasis online merupakan sarana yang efektif dalam mengelola data, pengoperasiannya juga cukup mudah, cepat, dan berbiaya murah [7].

Dalam perancangan sistem pengelolaan inventaris barang di Technical Departement IT di perusahaan Pertelevisian, Syakir (2011), memberikan penjelasan bahwa masih dilakukan secara manual meskipun sudah menggunakan komputer tetapi hanya sebagai media pendataan inventaris yang hanya bisa mendata barang yang ada di gudang, sedangkan barang masuk dan barang keluar serta barang yang rusak tidak terinventarisir. Oleh sebab itu, dibuatlah sistem informasi inventarisasi barang berbasis web. Sistem dibuat dengan menggunakan bahasa pemrograman PHP dan database MySQL. Sistem ini mencakup aspek dalam me-manage barang dengan baik sehingga barang dapat terorganisir serta diolah lebih baik lagi mulai dari pendataan barang yang masuk, pemindahan barang, pendataan barang yang rusak dan barang yang keluar [8].

Teknologi informasi juga dapat dimanfaatkan oleh desa yang cukup terpencil, untuk memudahkan para aparat desa dalam mengelola informasi desa. Penelitian ini dilakukan di Desa Kusik Batu Lapu yang merupakan desa yang berlokasi di 
pedalaman Kalimantan Barat, dengan jumlah penduduk 728 jiwa/204 KK. Desa Kusik Batu Lapu merupakan instansi pemerintahan yang bergerak dalam bidang pelayanan masyarakat. Pengumpulan dan penyimpanan segala bentuk dokumen desa akan lebih praktis jika digunakan sistem informasi berbasis komputer. Desa Kusik Batu Lapu masih banyak mengelola data secara manual salah satunya pengelolaan dan penyimpanan data inventaris barang. Pengelolaan dan penyimpanan data inventaris barang hanya dilakukan secara manual yaitu dengan menggunakan microsoft excel untuk mencatat semua data inventaris barang yang ada. Penelitian ini dilakukan di Desa Kusik Batu Lapu, di pedalaman Kalimantan Barat karena uniknya lokasi desa dan keinginan yang kuat dari kepala desa untuk membuktikan bahwa teknologi informasi juga dapat digunakan di desa terpencil sekalipun.

Selama ini, semua keterangan mengenai barang inventaris kantor dicatat dalam bentuk buku besar, sehingga untuk catatan barang-barang di tahun sebelumnya sebagian sudah tidak ada lagi dikarenakan pengelolaan data yang digunakan masih sangat sederhana. Jika ada pihak yang membutuhkan, sulit untuk mencari keterangan dimana dan apa saja data barang yang dibutuhkan, sehingga masih banyak kekurangan yang perlu diperbaiki untuk memperoleh hasil yang diinginkan. Oleh karena itu, perlu adanya suatu rancangan sistem informasi inventaris barang berbasis web di Kantor Desa Kusik Batu Lapu, Kalimantan Barat [9].

Untuk Sistem Informasi Inventaris Barang yang dirancang hampir sama dengan penelitian yang dilakukan oleh penelitian sebelumnya. Sistem yang dirancang berbasis web karena mudah dalam pengaksesannya, dengan menggunakan koneksi internet dapat diakses dimanapun dan kapanpun.

Tujuan yang hendak dicapai dalam penelitian kali ini adalah membuat sistem informasi inventaris barang di kantor Desa Kusik Batu Lapu, Kalimantan Barat dengan aplikasi berbasis website.

Manfaat Penelitian ini, antara lain :

1. Pengelolaan data inventaris barang yang mudah jika dibandingkan dengan penggunaan sistem konvensional.

2. Memberikan sistem informasi yang akurat untuk mengelola data barang inventaris di kantor Desa Kusik Batu Lapu, Kalimantan Barat.

3. Terwujudnya efektivitas dan efisiensi kerja khususnya pada bidang inventaris barang di kantor Desa Kusik Batu Lapu, Kalimantan Barat [10].

Aplikasi berbasis web sendiri merupakan sebuah program (software) yang dapat diakses melalui internet menggunakan web browser. Salah satu keuntungan membuat aplikasi berbasis web adalah bisa diakses dimana saja tanpa harus menginstall aplikasi lain, dikarenakan sudah terpasang di server, dan juga bisa digunakan pada sistem operasi apapun, baik yang menggunakan OS linux, windows, dan Mac OS [4].

Dalam pembuatan Sistem Informasi Inventaris Barang Berbasis Web di Kantor Desa Kusik Batu Lapu, Kalimantan Barat, sebagai referensi digunakan beberapa literature mengenai sistem informasi yang akan dibangun berdasarkan sumbersumber pustaka untuk menjadi panduan sebagai pendukung pembuatan project/rancangan aplikasi yang dibuat.

Dari hasil pembuatan dan perancangan menggunakan beberapa tools pendukung antara lain: XAMPP, Sublime text-3, dan Notepad++. Untuk aplikasi XAMPP sendiri digunakan sebagai localhost, yang di dalam fiturnya terdapat file Zilla, MySQL, dan Apache. Software ini sangat mendukung bahasa pemrograman berupa PHP yang digunakan untuk membuat sebuah rancangan website dinamis.Operation System(OS) yang mendukung adalah linux dan windows. Sedangkan untuk software sublime text-3 dan notepad++ berfungsi sebagai aplikasi editor text, untuk menulis kode, biasa digunakan dalam bahasa pemrograman seperti : PHP, CSS, C, C++, HTML, ASP, dan Java [3].

\section{METODE PENELITIAN}

\section{A. Metode Wawancara}

Wawancara merupakan suatu teknik pengumpulan data secara langsung, saling bertukar pikiran dan berbagi informasi dengan kepala desa dan bagian perangkat desa yang menangani sarana dan prasarana desa mengenai permasalahan pengelolaan data inventaris barang yang masih dilakukan secara manual pada kantor Desa Kusik Batu Lapu, Kalimantan Barat. Untuk bentuk laporan, dengan melakukan wawancara secara daring(online), dikarenakan dilakukan di masa pandemic covid-19, untuk aplikasi yang yang digunakan yaitu via whatsapp, google meet untuk melakukan videocall dan berbagi informasi seputar inventaris barang yang ada di kantor Desa Kusik Batu Lapu, Kalimantan Barat.

B. Metode Dokumentasi

Proses Pengambilan data dengan media gambar, data tertulis, dan arsip yang diizinkan dari pihak Desa Kusik Batu Lapu, Kalimantan Barat, sebagai gambaran dalam penyusunan laporan tugas akhir.

C. Studi Pustaka

Metode yang digunakan untuk mencari landasan teori dari berbagai literature yang berkaitan dengan masalah penelitian yang akan lakukan. Studi pustaka ini dilakukan dengan membaca buku-buku yang ada di perpustakaan dan dari sumbersumber terpercaya sebagai panduan, serta literature lain yang berkaitan dengan bidang penelitian yang dilakukan.

Untuk melakukan penelitian, langkah yang dilakukan yaitu dengan membuat beberapa kuesioner dan dibagikan ke 11 responden pegawai/perangkat desa Kusik Batu Lapu, kalimantan Barat, kemudian data tersebut dijadikan subjek penelitian 
dari hasil pengisian kuesioner Perancangan Sistem Informasi Inventaris Barang Berbasis Web Di Kantor Desa Kusik Batu Lapu Kalimantan Barat.

Dalam kuesioner ini terdapat 10 pertanyaan yang harus dijawab oleh responden, dimana setiap responden harus memilih salah satu opsi dari setiap pertanyaan.Apakah responden Sangat Setuju, Setuju, Netral, Tidak Setuju, dan Sangat Tidak Setuju.

\section{KUISIONER PENELITIAN}

\section{Perancangan Sistem Informasi Inventaris Barang Berbasis Web Di Kantor Desa Kusik Batu Lapu Kalimantan Barat}

Nama Lengkap

Jenis Kelamin

Alamat

Jabatan

Berikan tanda centang $(\sqrt{ })$ pada nilai yang anda anggap sesuai

Keterangan :

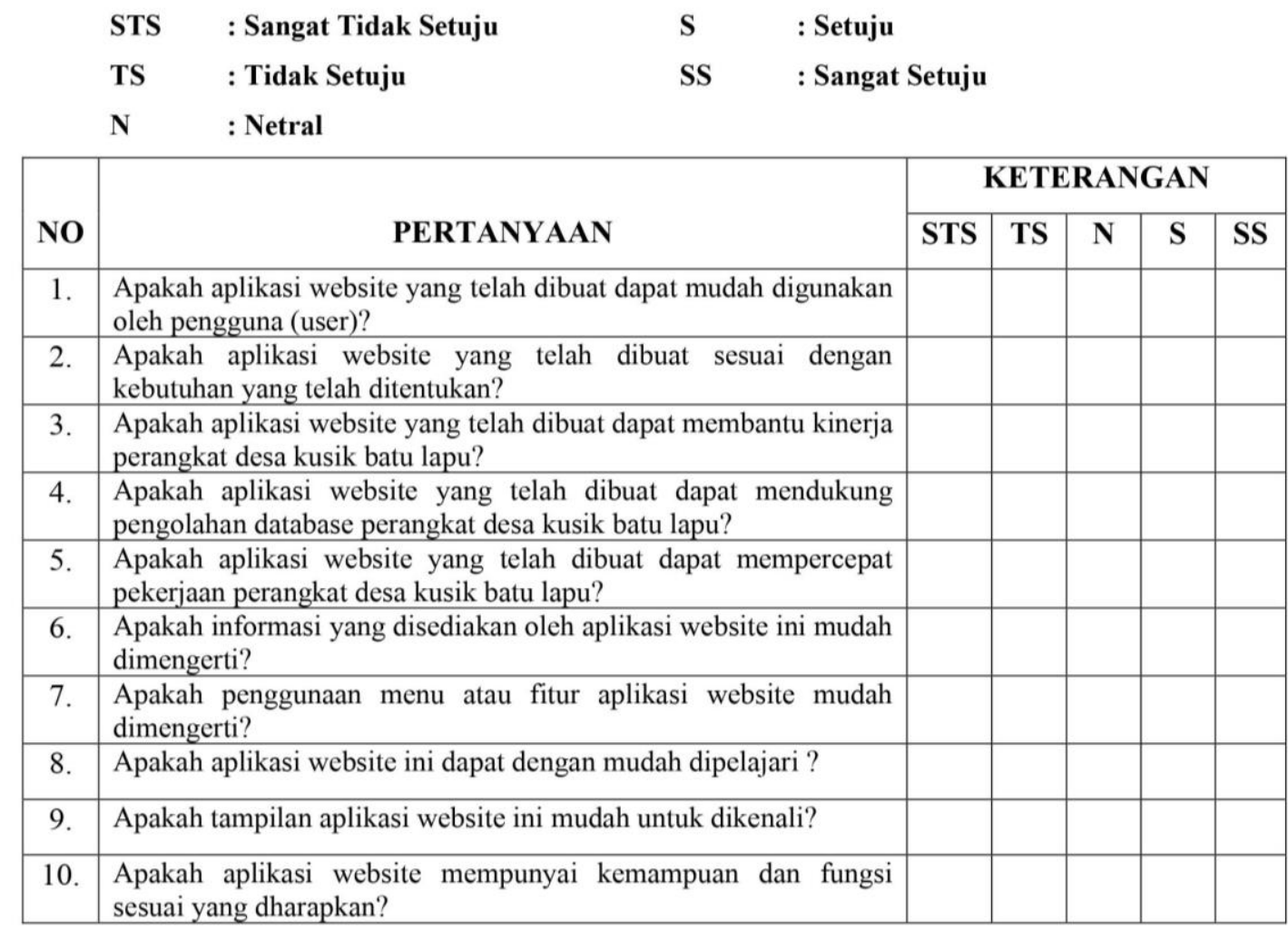

\section{Gambar 1. Kuesioner Penelitian}

Pada Gambar 1. ditampilkan kuesioner penelitian yang menjelaskan bagaimana proses penelitian dilakukan dengan cara membagikan kuesioner kepada seluruh perangkat Desa Kusik Batu Lapu, Kalimantan Barat. 


\section{HASIL DAN PEMBAHASAN}

A. Laporan Hasil Penelitian

1) Latar belakang penelitian: Website merupakan kumpulan halaman yang menampilkan berbagai macam informasi teks, animasi, data dan gambar yang diam maupun yang bisa bergerak, suara, dan video. Bersifat statis maupun dinamis, yang akan membentuk rangkaian bangunan yang saling berkaitan, dan bisa terhubung satu sama lain, dengan jaringan halaman internet (hyperlink) [12].

Website pengelolaan data inventaris barang didesain untuk mempermudah kinerja perangkat desa, khususnya di kantor desa Kusik Batu Lapu, Kalimantan Barat. Website ini didukung dengan menu atau fitur yang tidak terlalu rumit, mudah dipelajari dan mudah untuk dioperasikan atau digunakan oleh si penggunanya [6].

Penggunaan website ini dapat dijadikan sebagai program unggulan sebuah instansi pemerintahan, khususnya di desa Kusik Batu Lapu, Kalimantan Barat. Terlebih di dalam website ini terdapat sistem yang memungkinkan perangkat desa dengan mudah mengelola data barang secara online tanpa harus menggunakan buku secara manual. Hal ini yang mendasari untuk melakukan penelitian dan membuat perancangan sistem secara efektif di desa Kusik Batu Lapu, Kalimantan Barat.

2) Tempat dan Waktu Kegiatan Tempat Waktu

: Adapun tempat dan waktu penyebaran kuesioner ini dilaksanakan pada:

: Kantor Desa Kusik Batu Lapu, Kalimantan Barat

: Senin, 29 Maret 2021 pukul 08.00 WIB - 14.00 WIB

3) Tujuan dan Manfaat: Tujuan penelitian ini adalah untuk memenuhi persyaratan dalam mengambil mata kuliah Tugas Akhir, adapun tujuan lainnya yaitu untuk melakukan penelitian dan membuat perancangan sistem informasi data barang, dimana di desa Kusik Batu Lapu, semua data barang dicatat menggunakan buku besar secara manual.Sehingga diharapkan dengan adanya sistem informasi inventaris barang di Desa Kusik Batu Lapu, Kalimantan Barat, dapat meningkatkan kinerja perangkat desa dalam mengelola data barang [11]. Berdasarkan analisis dan pengamatan yang dilakukan di Kantor Desa Kusik Batu Lapu, Kalimantan Barat, dapat ditarik kesimpulan:

1. Proses pencatatan barang masuk, dan barang keluar masih manual.

2. Proses pembuatan laporan buku besar masih manual

4) Hipotesis: Berdasarkan hasil survey dari penelitian ini, website Sistem Informasi Inventaris Barang memiliki antarmuka atau tampilan dan menu-menu yang mudah dimengerti. Namun demikian masih ada beberapa orang yang masih tidak paham mempelajari cara kerja sistem tersebut. Hal ini kemungkinan karena kurang pengetahuan dan informasi yang memadai, sehingga perlu waktu untuk mempelajarinya. Seluruh perangkat desa diharapkan bisa menggunakannya walaupun membutuhkan waktu beberapa hari.

5) Metode Penelitian: Metode penelitian yang lakukan yaitu dengan membuat beberapa kuesioner dan dibagikan ke 11 responden pegawai/perangkat desa Kusik Batu Lapu, Kalimantan Barat, kemudian data tersebut dijadikan subjek penelitian dari hasil pengisian kuesioner Perancangan Sistem Informasi Inventaris Barang Berbasis Web Di Kantor Desa Kusik Batu Lapu Kalimantan Barat [2].

6) Hasil responden penelitian: Data responden dari 11 kuesioner dirangkum ke dalam tabel yang terlihat di tabel 1.

TABEL 1

DAta TABel Hasil KuEsioner PENELITIAN

\begin{tabular}{|c|c|c|c|c|c|c|c|c|c|c|c|c|c|}
\hline No & $\underset{\text { Lengkap }}{\text { Nama }}$ & $\begin{array}{l}\text { Jenis } \\
\text { Kelamin }\end{array}$ & Alamat & Jabatan & 1 & 2 & 3 & 4 & 5 & 6 & 8 & 9 & $\overline{10}$ \\
\hline 1 & Andreas Sino & Laki-Laki & $\begin{array}{l}\text { Kusik } \\
\text { Bulin }\end{array}$ & Kepala Desa & $\mathrm{S}$ & $\mathrm{S}$ & SS & SS & $\mathrm{S}$ & $\mathrm{S}$ & SS & $\mathrm{S}$ & $\mathrm{S}$ \\
\hline 2 & $\begin{array}{l}\text { Andreas } \\
\text { Contoh }\end{array}$ & Laki-Laki & $\begin{array}{l}\text { Kusik } \\
\text { Bulin }\end{array}$ & Sekretaris Desa & $\mathrm{S}$ & $\mathrm{N}$ & SS & $\mathrm{S}$ & $\mathrm{S}$ & $\mathrm{S} S \mathrm{SS}$ & $\mathrm{S}$ & $\mathrm{S}$ & SS \\
\hline 3 & Idi Santoso & Laki-Laki & $\begin{array}{c}\text { Batu } \\
\text { Menang }\end{array}$ & Bendahara & $\mathrm{S}$ & $\mathrm{S}$ & SS & $\mathrm{S}$ & SS & $\mathrm{S} \quad \mathrm{SS}$ & $\mathrm{S}$ & $\mathrm{S}$ & $\mathrm{S}$ \\
\hline 4 & Bodi Handika & Laki-Laki & Batu Lapu & $\begin{array}{c}\text { KASI } \\
\text { Pemerintahan }\end{array}$ & TS & $\mathrm{N}$ & $\mathrm{S}$ & $\mathrm{N}$ & $\mathrm{S}$ & $\mathrm{S}$ & TS & $\mathrm{N}$ & $\mathrm{S}$ \\
\hline 5 & Jedi Irawan & Laki-Laki & $\begin{array}{l}\text { Kusik } \\
\text { Bulin } \\
\end{array}$ & $\begin{array}{c}\text { Kaur } \\
\text { Perencanaan }\end{array}$ & SS & $\mathrm{S}$ & $\mathrm{S}$ & SS & $\mathrm{S}$ & $\mathrm{S}$ & $\mathrm{S}$ & SS & SS \\
\hline 6 & $\begin{array}{l}\text { Venansius } \\
\text { Aldi }\end{array}$ & Laki-Laki & Batu Lapu & KASI Pelayanan & SS & $\mathrm{S}$ & $\mathrm{S}$ & SS & $\mathrm{S}$ & $\mathrm{SS}^{-}$ & $\mathrm{S}$ & $\mathrm{S}$ & $\mathrm{S}$ \\
\hline 7 & M.Susandra & Perempuan & $\begin{array}{l}\text { Kusik } \\
\text { Bulin }\end{array}$ & $\begin{array}{c}\text { KASI } \\
\text { Kesejahteraan }\end{array}$ & SS & $\mathrm{S}$ & SS & SS & $\mathrm{S}$ & $\mathrm{S}$ SS & $\mathrm{S}$ & $\mathrm{S}$ & SS \\
\hline 8 & Rupindi & Laki-Laki & $\begin{array}{l}\text { Kusik } \\
\text { Bulin }\end{array}$ & Kaur Umum & SS & SS & SS & SS & SS & SS SS & SS & SS & SS \\
\hline 9 & Yuliana Mimi & Perempuan & $\begin{array}{l}\text { Batu } \\
\text { Menang }\end{array}$ & $\begin{array}{c}\text { Unsur } \\
\text { Kewilayahan }\end{array}$ & $\mathrm{N}$ & $\mathrm{S}$ & $\mathrm{S}$ & SS & $\mathrm{S}$ & SS SS & $\mathrm{S}$ & SS & $\mathrm{S}$ \\
\hline 10 & Romiyanto & Laki-Laki & $\begin{array}{l}\text { Kusik } \\
\text { Bulin }\end{array}$ & $\begin{array}{c}\text { Unsur } \\
\text { Kewilayahan }\end{array}$ & $\mathrm{N}$ & $\mathrm{S}$ & SS & $\mathrm{S}$ & $\mathrm{S}$ & $\mathrm{S}^{-}$ & $\mathrm{S}$ & $\mathrm{S}$ & $\mathrm{S}$ \\
\hline 11 & Koko Berto & Laki-Laki & $\begin{array}{l}\text { Kusik } \\
\text { Bulin } \\
\end{array}$ & $\begin{array}{c}\text { Unsur } \\
\text { Kewilayahan } \\
\end{array}$ & S & SS & SS & $\mathrm{S}$ & $\mathrm{S}$ & SS SS & S & $\mathrm{S}$ & $\mathrm{S}$ \\
\hline
\end{tabular}


7) Dokumentasi Penelitian: Dokumen penelitian ini berupa gambar/foto yang dilakukan secara online via google meet dan diminta bantu pihak desa untuk mengambil gambar secara langsung di Kantor Desa Kusik Batu Lapu, Kalimantan Barat, serta memandu sistem aplikasi yang sudah dibuat agar bisa dijalankan secara daring (online). Berikut dokumentasi beserta arsip desa yang sudah didapatkan:

1. Arsip Buku Inventaris Barang di Desa Kusik Batu Lapu, Kalimantan Barat.

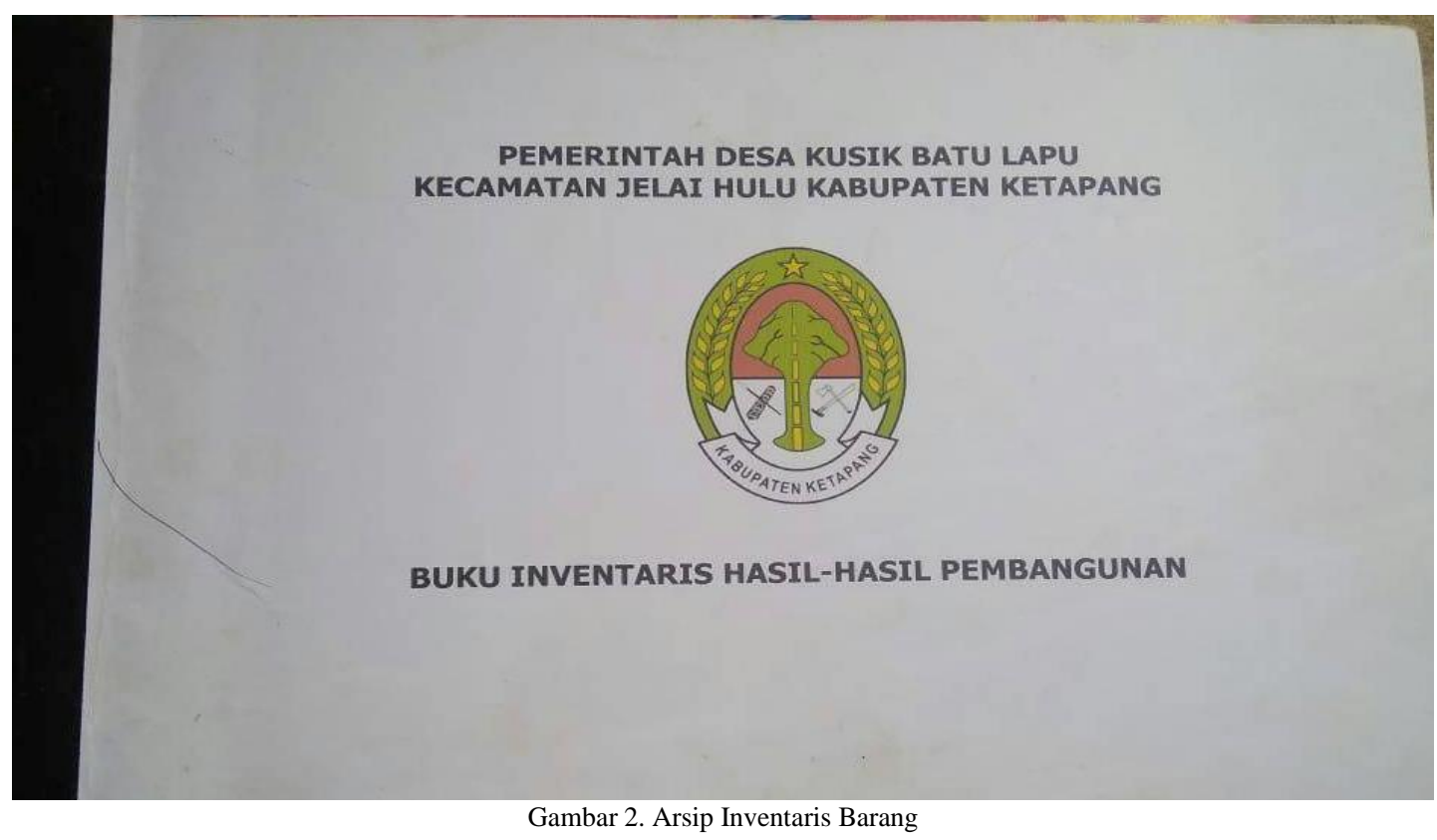

Pada Gambar 2. ditampilkan arsip inventaris barang yang menjelaskan bagaimana proses input data masih dilakukan secara manual menggunakan buku besar/buku inventaris barang.

2. Buku inventaris dan kekayaan desa di Desa Kusik Batu Lapu, Kalimantan Barat.

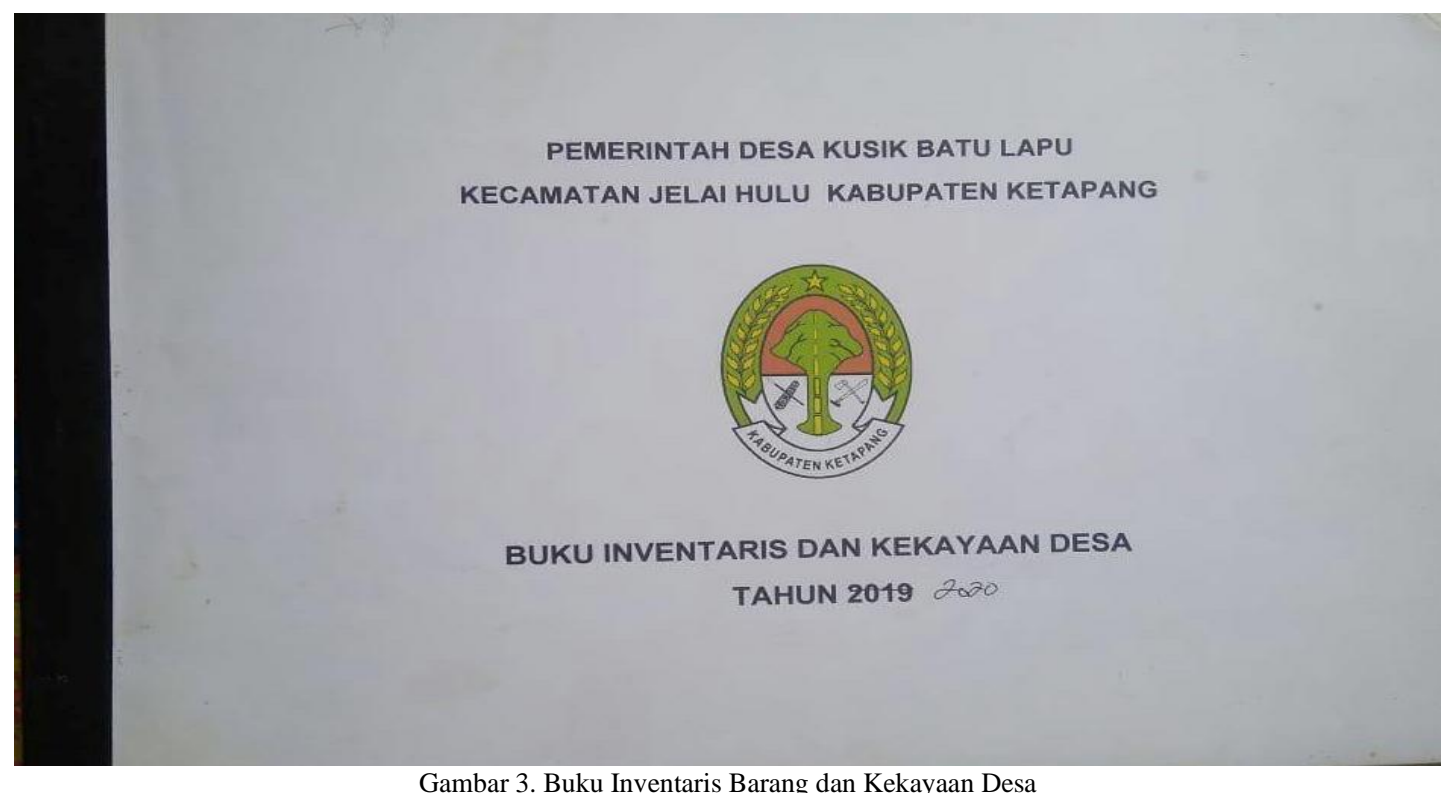

Pada Gambar 3. ditampilkan buku inventaris barang dan kekayaan desa yang merupakan contoh arsip barang yang digunakan masih secara manual. 
3. Isi buku inventaris Hasil Pembangunan di Desa Kusik Batu Lapu.

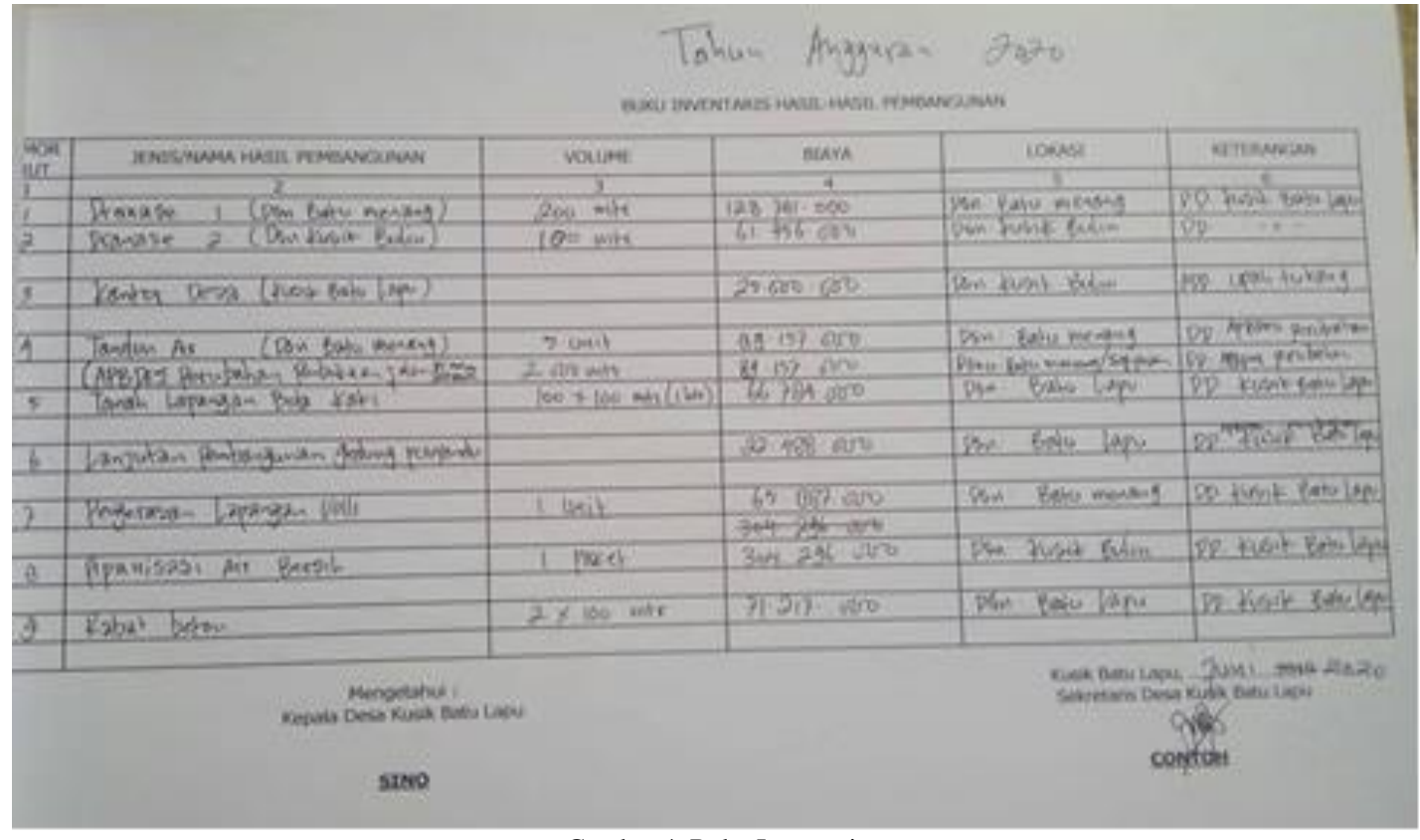

Gambar 4. Buku Inventaris

Pada Gambar 4. ditampilkan buku inventaris yang merupakan salah satu arsip data barang yang ada di Desa Kusik Batu Lapu, Kalimantan Barat.

4. Dokumen hasil simulasi aplikasi di Desa Kusik Batu Lapu.

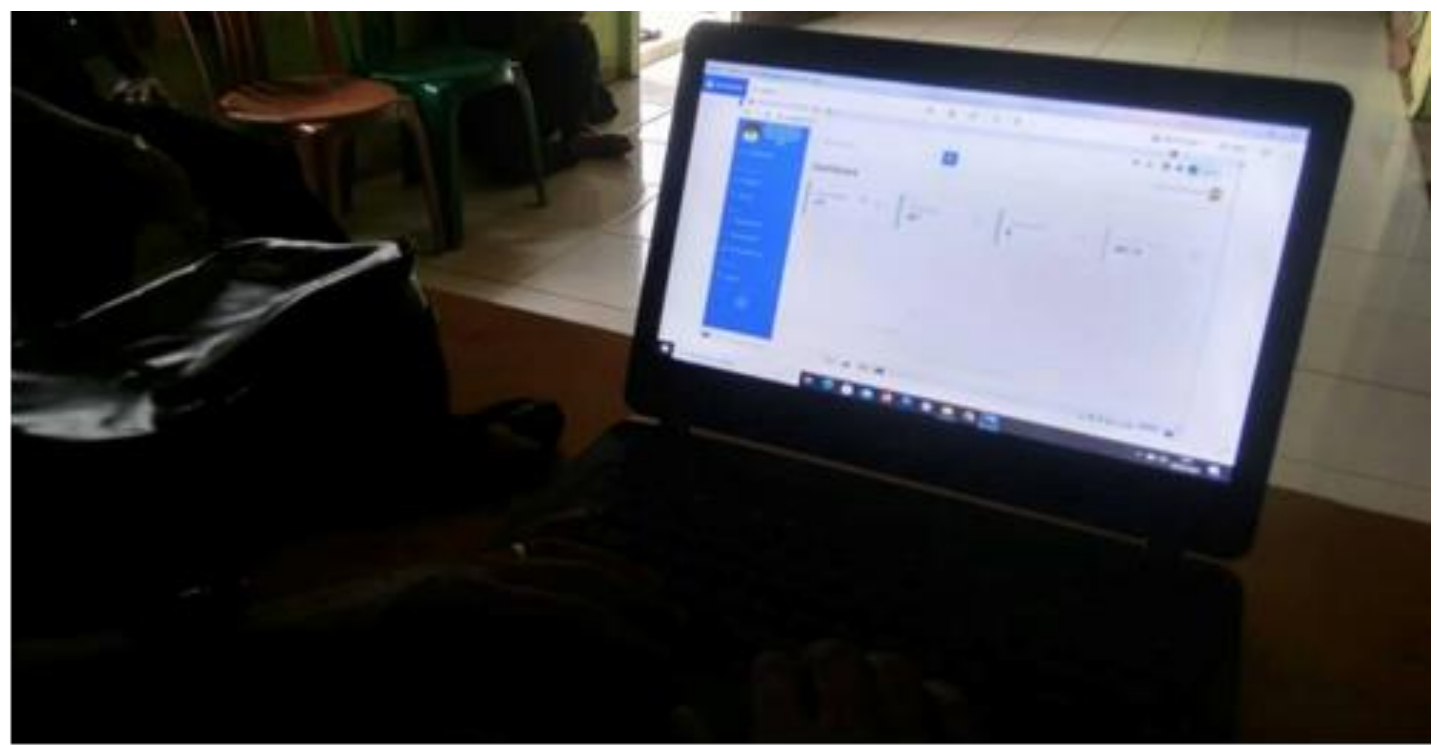

Gambar 5. Dokumen Simulasi Aplikasi

Pada Gambar 5. ditampilkan dokumen simulasi aplikasi yang menjelaskan bagaimana cara kerja sistem yang sudah di rancang, agar dapat digunakan dengan baik oleh perangkat desa Kusik Batu Lapu, Kalimantan Barat. 


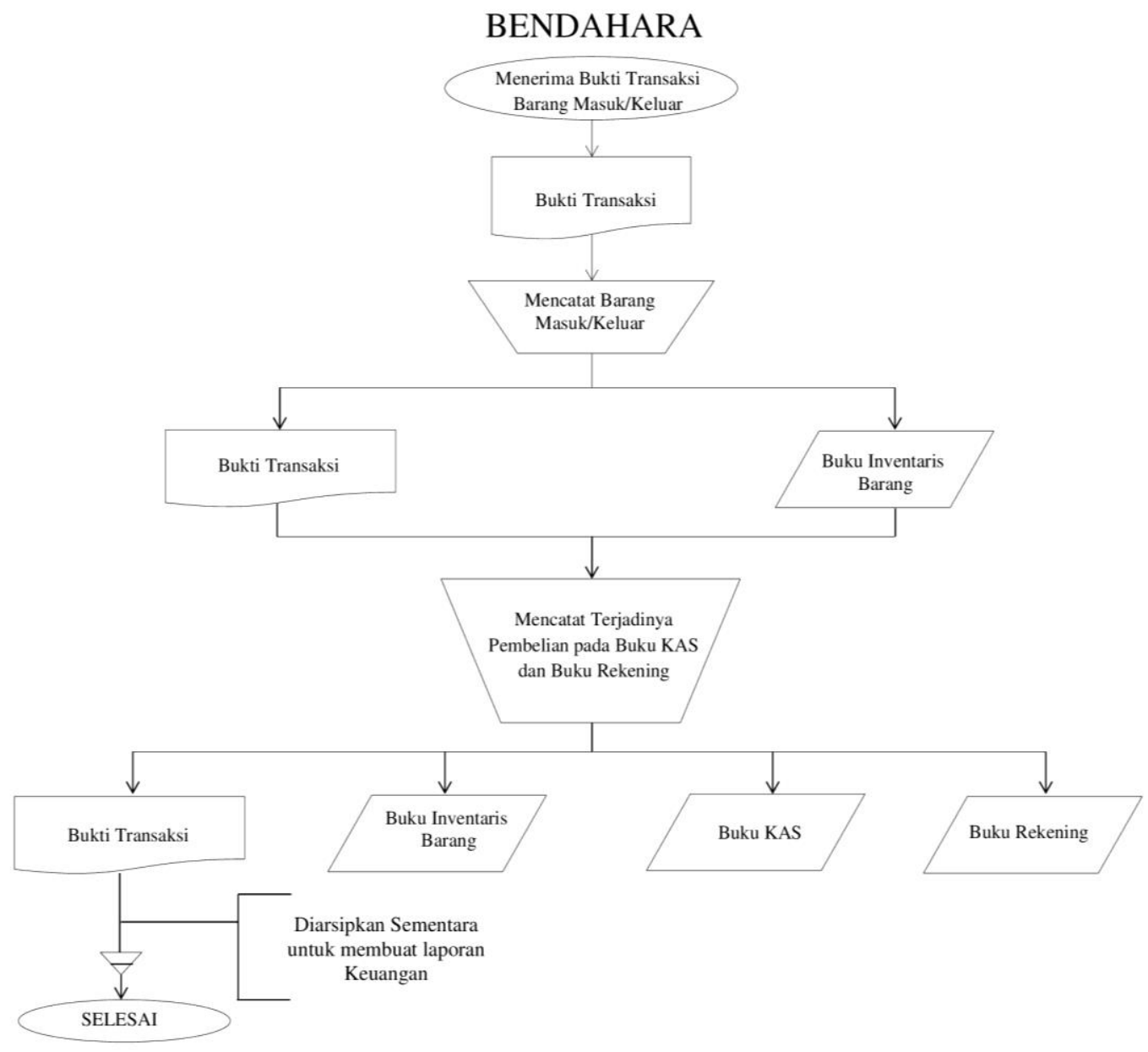

Gambar 6. Flowchart Bendahara

Pada Gambar 6. ditampilkan Flowchart bendahara yang menyajikan alur urutan proses sistem informasi inventaris barang, dimana admin sebagai aktor dalam menjalankan aplikasi ini.

1. Bendahara menerima bukti transaksi pembelian barang, data barang sendiri dibagi menjadi dua, barang masuk dan barang keluar.

2. Kemudian bendahara mencatat data barang yang dibeli pada buku inventaris kantor.

3. Selanjutnya bendahara mencatat transaksi pembelian pada buku kas dan buku rekening,

4. Setelah itu bukti diarsipkan sementara untuk menyiapkan laporan keuangan pada akhir bulan.

C. Dokumen yang terkait

1. Bukti Transaksi (Bank Keluar)

Data transaksi kas masuk ketika melakukan penarikan uang dari Bank.

2. Nota(Bukti Kas Masuk)

Data transaksi dari pembelian barang-barang.

D. Aturan Bisnis

1. Sistem yang dirancang hanya digunakan untuk kantor Desa Kusik Batu Lapu saja.

2. Sistem hanya bisa dioperasikan atau diakses oleh bendahara saja sebagai admin.

3. Semua data barang kantor Desa Kusik Batu Lapu dan data transaksi hanya bisa diinputkan oleh bendahara.

4. Transaksi yang diinputkan tidak dapat diedit, harus dihapus dahulu baru bisa menginputkan kembali, karena tidak ada menu edit. 


\section{E. Data Flow Diagram(DFD)}

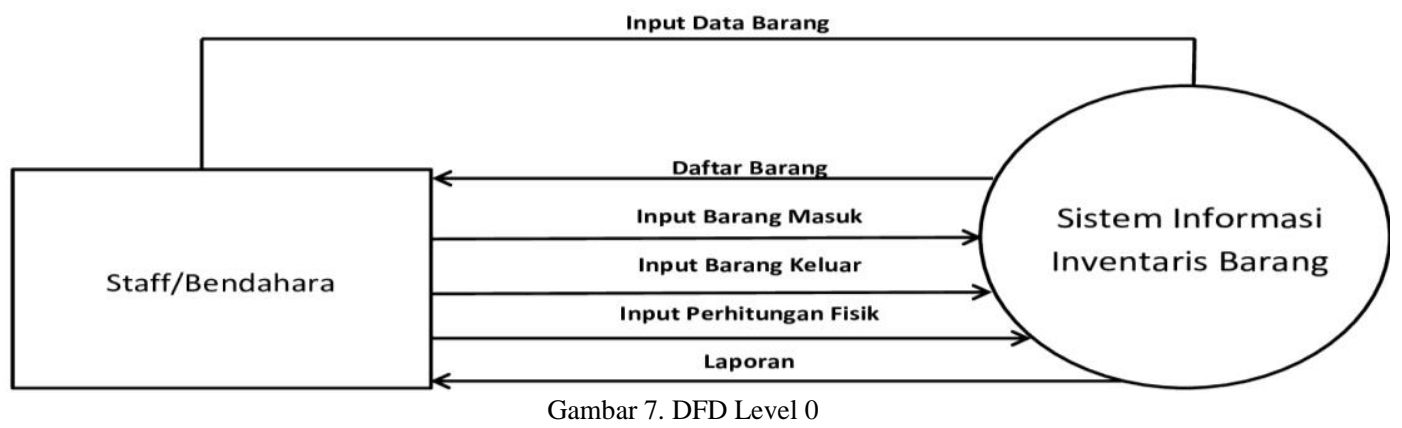

Pada Gambar 7. ditampilkan DFD level 0 yang menyajikan sistem informasi inventaris hanya memiliki satu entitas yaitu staff. Entitas staff berperan penting dalam melakukan penginputan seperti data barang, daftar barang, input barang masuk, input barang keluar, input perhitungan fisik dan diproses melalui laporan.

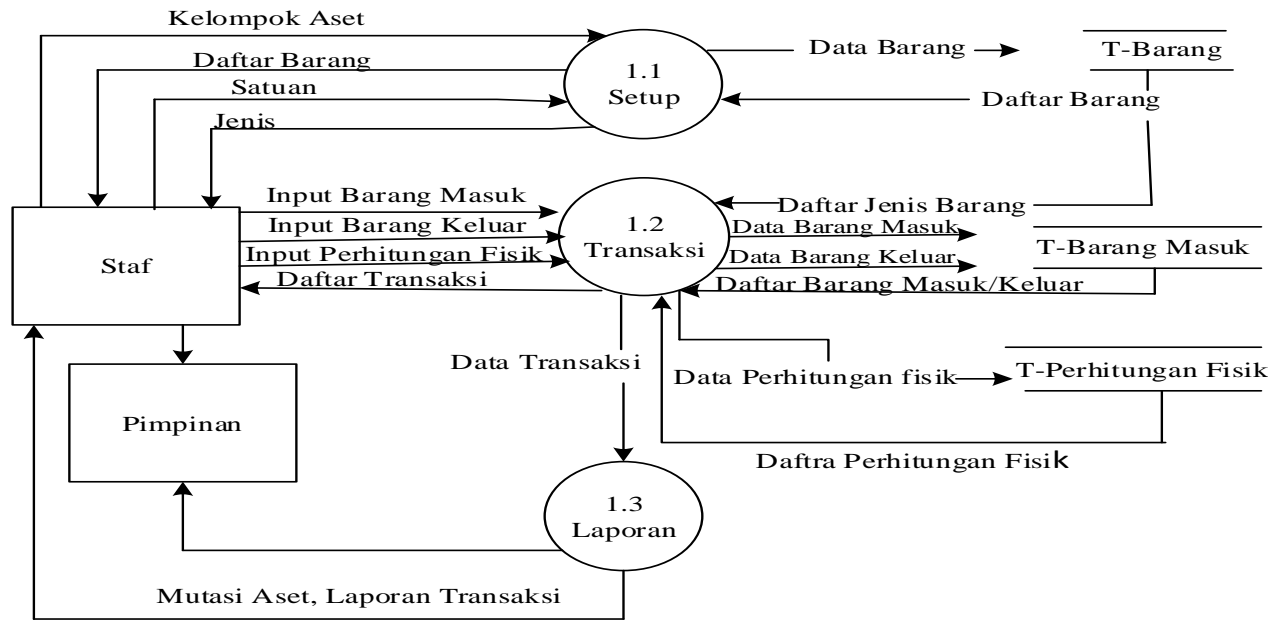

Gambar 8. DFD Level 1

Pada Gambar 8. ditampilkan DFD level 1 yang menjelaskan bahwa sistem informasi Inventaris Barang memiliki 3 proses yaitu setup, transaksi dan laporan. Bagian proses setup dijelaskan staff melakukan penginputan kelompok aset, jenis barang, nama satuan,dan data barang yang kemudian diolah dan disimpan ke dalam tabel barang, dari tabel barang maka staff dapat mengetahui daftar jenis-jenis barang. Kemudian untuk digunakan data tersebut, untuk melakukan penginputan data barang masuk dan keluar ataupun perhitungan fisik (kebutuhan transaksi), bahwa tabel barang masuk digunakan untuk dua jenis data, barang masuk dan keluar, dan untuk mendapatkan data barang keluar hanya memerlukan perubahan status keluar pada data masuk di tabel barang masuk. Dari penginputan data transaksi tersebut staf akan mendapatkan daftar transaksi yang akan otomatis diolah oleh sistem untuk menghasilkan laporan mutasi aset dan laporan barang masuk atau barang keluar. 


\section{F. Entity Relationship Diagram (ERD)}

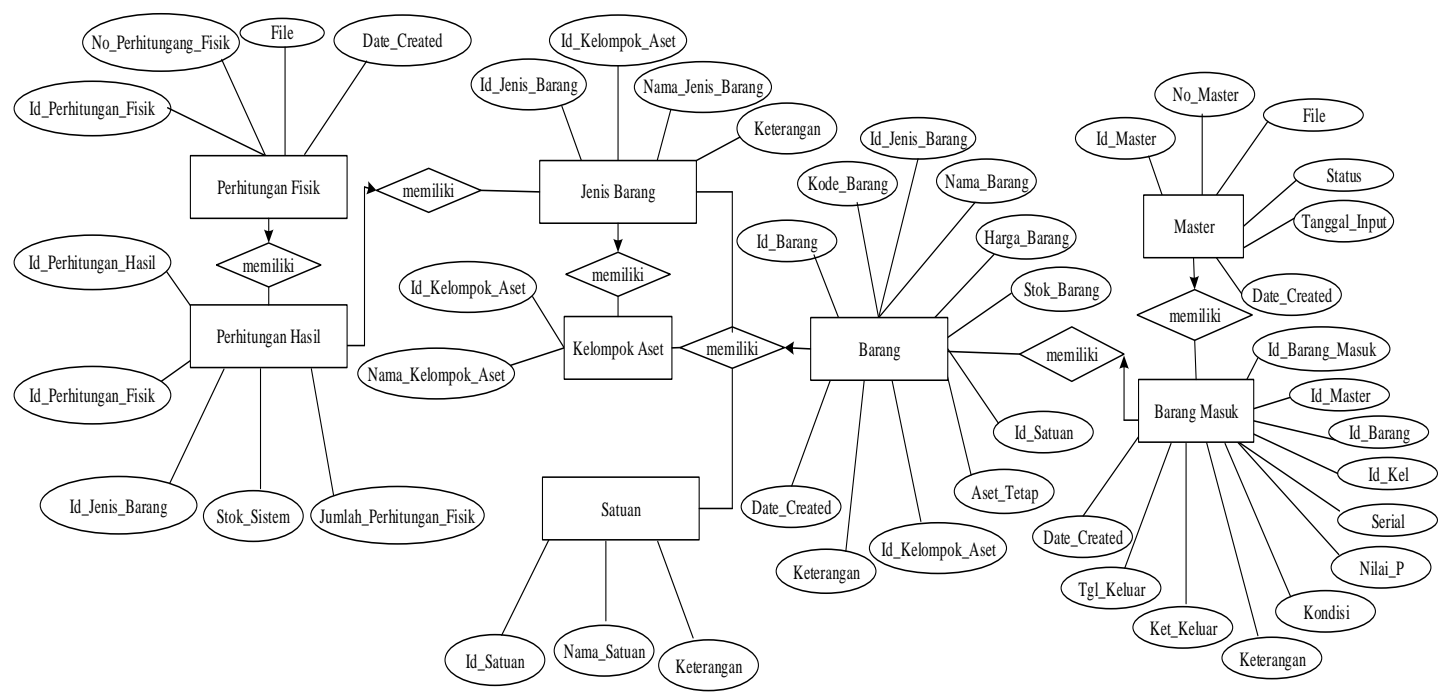

Gambar 9. Entity Relationship Diagram (ERD)

Pada Gambar 9. ditampilkan ERD yang menjelaskan dalam sistem ini memiliki 8 entitas yaitu barang, jenis, satuan, master, kelompok_aset, barang_masuk, perhitungan_fisik dan perhitungan_hasil. Dalam barang memiliki empat atribut primary key yaitu ID, tujuh atribut mandatory yaitu kode_barang, nama_barang, harga_barang, stok_barang, aset_tetap, keterangan dan date_created. Dalam entitas barang_masuk memiliki empat atribut primary key yaitu id, tujuh atribut mandatory yaitu serial, nilai_p, kondisi, ket_keluar, keterangan, tanggal_keluar dan date_created. Dalam entitas jenis memiliki satu atribut primary key yaitu id, dua atribut mandatory yaitu nama_jenis dan keterangan. Dalam entitas satuan memiliki satu atribut primary key yaitu id, dua atribut mandatory yaitu nama_satuan dan keterangan_satuan. Dalam entitas master memiliki satu atribut primary key yaitu id, lima atribut mandatory yaitu no_master, file, status, tanggal_input dan date_created. Dalam entitas perhitungan fisik memiliki satu atribut primary key yaitu id, tiga atribut mandatory yaitu no_perhitungan_fisik, file dan date_created. Dalam entitas perhitungan hasil memiliki tiga primary key yaitu id, dua atribut mandatory yaitu stok_sistem dan jumlah_perhitungan_fisik.

\section{G. Tabel}

Untuk relasi desain tabel user, dapat disederhanakan dengan self relation, yang dapat terlihat pada tabel 2.

TABEL 2

TABEL USER

\begin{tabular}{llll}
\hline No & \multicolumn{1}{c}{ Nama } & \multicolumn{1}{c}{ Type } & \multicolumn{1}{c}{ Keterangan } \\
\hline 1. & Id & Int (11) & Id sebagai primary key \\
\hline 2. & Role User & Int (11) & Role User sebagai identitas pengguna atau yang berperan untuk melakukan login \\
\hline 3. & Nama User & Varchar (30) & Nama User/ pengguna \\
\hline 4. & Username & Varchar (30) & Username sebagai nama yang digunakan ketika login \\
\hline 5. & Jabatan & Varchar (30) & Jabatan sebagai nama untuk mengetahui jabatannya \\
\hline 6. & Password & Varchar (30) & Password digunakan sebagai kunci aset ketika login \\
\hline
\end{tabular}

Untuk relasi desain tabel barang, dapat disederhanakan dengan self relation, yang dapat terlihat pada tabel 3. 
TABEL 3

TABEL BARANG

\begin{tabular}{llll}
\hline NO & Nama & Type & Keterangan \\
\hline $\mathbf{1 .}$ & Id_Barang & Int (11) & ID Barang sebagai primary key \\
\hline $\mathbf{2 .}$ & Kode_Barang & Int (11) & Kode Barang untuk mengetahui setiap kode barang \\
\hline $\mathbf{3 .}$ & Id_Jenis_Barang & Int (11) & ID Jenis Barang sebagai primary key \\
\hline $\mathbf{5 .}$ & Nama_Barang & Varchar (128) & Nama Barang sebagai keterangan dari kode barang \\
\hline $\mathbf{6 .}$ & Stok_stok & Int (11) & Harga Barang berfungsi untuk mengetahui harga item tersebut \\
\hline $\mathbf{7 .}$ & Id_Satuan & Int (11) & Stok Barang untuk mengetahui masih ada berapa stok barang \\
\hline $\mathbf{8 .}$ & Aset_Tetap & Int (11) & ID Satuan sebagai primary key \\
\hline $\mathbf{9 .}$ & Id_Kelompok_Aset & Int (11) & Aset Tetap untuk mengetahui dari barang dari tabel aset tetap \\
\hline $\mathbf{1 0 .}$ & Keterangan & Varchar (128) & Keterangan untuk barang masuk atau keluar \\
\hline $\mathbf{1 1 .}$ & Date_Created & Int (11) & Date Created untuk mengetahui tanggal cetak atau pembuatan \\
\hline
\end{tabular}

Untuk relasi desain tabel barang masuk, dapat disederhanakan dengan self relation, yang dapat terlihat pada tabel 4.

TABEL 4

TABEL BARANG MASUK

\begin{tabular}{|c|c|c|c|}
\hline No & Nama & Type & Keterangan \\
\hline 1. & Id_Barang_Masuk & Int (11) & ID Barang Masuk sebagai primary key \\
\hline 2. & Id_Master & Int (11) & ID Master sebagai primary key \\
\hline 3. & Id_Barang & Int (11) & ID Barang sebagai primary key \\
\hline 4. & Id_Kel & Int (11) & ID Kel sebagai foreign key \\
\hline 5. & Serial & Varchar (20) & Serial kode seri dari aset \\
\hline 6. & Kondisi & Varchar (20) & Kondisi untuk mengetahui baik maupun buruknya suatu barang \\
\hline 8. & Keterangan & Varchar (222) & Keterangan untuk mengetahui id masuk dan id barang \\
\hline 9. & Ket_Keluar & Varchar (300) & Ket keluaran untuk mengetahui barang apa saja yang keluar \\
\hline 10. & Tgl_Keluar & Int (11) & Tgl keluar untuk mengetahui tgl barang keluar \\
\hline 11. & Date_Created & Int (11) & Date Created untuk mengetahui tanggal cetak atau pembuatan \\
\hline
\end{tabular}

Untuk relasi desain tabel jenis barang, dapat disederhanakan dengan self relation, yang dapat terlihat pada tabel 5.

TABEL 5

TABEL JENIS BARANG

\begin{tabular}{llll}
\hline No & Nama & Type & Keterangan \\
\hline 1. & Id_Jenis_Barang & Int (11) & ID Jenis Barang sebagai primary key \\
\hline 2. & Id_Kelompok_Aset & Int (11) & ID Kelompok Aset sebagai primary key \\
\hline 3. & Nama_Jenis_Barang & $\begin{array}{l}\text { Varchar } \\
(20)\end{array}$ & Nama Jenis Barang sebagai keterangan dari id jenis barang \\
\hline 4. & Keterangan & $\begin{array}{l}\text { Varchar } \\
(123)\end{array}$ & Keterangan untuk mengetahui jenis barang \\
\hline
\end{tabular}

Untuk relasi desain tabel laporan, dapat disederhanakan dengan self relation, yang dapat terlihat pada tabel 6.

TABEL 6

TABEL LAPORAN

\begin{tabular}{llll}
\hline No & Nama & Type & Keterangan \\
\hline 1. & Id_Laporan & Int (11) & ID Laporan sebagai primary key \\
\hline 2. & Nama_Laporan & Varchar (128) & Nama Laporan sebagai keterangan dari id laporan \\
\hline 3. & Awal_Laporan & Int (11) & Awal Laporan untuk mengetahui jumlah saldo awal laporan \\
\hline
\end{tabular}




\begin{tabular}{llll}
\hline No & Nama & Type & Keterangan \\
\hline $\mathbf{4 .}$ & Akhir_Laporan & Int (11) & Akhir Laporan untuk mengetahui jumlah saldo akhir laporan \\
\hline $\mathbf{5 .}$ & Date_Created & Int (11) & Date Created untuk mengetahui tanggal cetak atau pembuatan \\
\hline
\end{tabular}

Untuk relasi desain tabel master, dapat disederhanakan dengan self relation, yang dapat terlihat pada tabel 7.

TABEL 7

TABEL MASTER

\begin{tabular}{llll}
\hline No & Nama & Type & Keterangan \\
\hline $\mathbf{1 .}$ & Id_Master & Int (11) & ID Master sebagai primary key \\
\hline $\mathbf{2 .}$ & No_Master & Int (11) & No Master untuk mengetahui barang \\
\hline $\mathbf{3 .}$ & File & Varchar (50) & File untuk mengetahui sebagai bukti transaksi \\
\hline $\mathbf{4 .}$ & Status & Int (11) & Status untuk mengetahui status suatu barang \\
\hline $\mathbf{5 .}$ & Tanggal_Input & Int (11) & Tanggal input untuk mengetahui tanggal barang yang diinput \\
\hline $\mathbf{6 .}$ & Date_Created & Int (11) & Date Created untuk mengetahui tanggal cetak atau pembuatan
\end{tabular}

Untuk relasi desain tabel satuan, dapat disederhanakan dengan self relation, yang dapat terlihat pada tabel 8 .

TABEL 8

TABEL SATUAN

\begin{tabular}{llll}
\hline No & Nama & Type & Keterangan \\
\hline 1. & Id_Satuan & Int $(11)$ & ID Satuan sebagai primary key \\
\hline 2. & Nama_Satuan & Varchar $(50)$ & Nama Satuan Untuk mengetahui dari id satuan barang \\
\hline 3. & Keterangan & Varchar $(128)$ & Keterangan untuk mengetahui nama barang \\
\hline
\end{tabular}

Untuk relasi desain tabel kelompok aset, dapat disederhanakan dengan self relation, yang dapat terlihat pada tabel 9.

TABEL 9

TABEL KELOMPOK ASET

\begin{tabular}{llll}
\hline No & Nama & Type & Keterangan \\
\hline 1. & Id_Kelompok_Aset & Int (11) & ID Kelompok Aset sebagai primary key \\
\hline 2. & Nama_Kelompok_Aset & Varchar (50) & Nama Kelompok Aset untuk mengetahui kelompok barang apa saja
\end{tabular}

Untuk relasi desain tabel perhitungan fisik, dapat disederhanakan dengan self relation, yang dapat terlihat pada tabel 10.

TABEL 10

TABel PERHITUNGAN FisiK

\begin{tabular}{llll}
\hline No & Nama & Type & Keterangan \\
\hline 1. & Id_Perhitungan_Fisik & Int (11) & ID Perhitungan Fisik sebagai primary key \\
\hline 2. & No_Perhitungan_Fisik & Varchar (20) & No Perhitungan Fisik untuk mengetahui no dari perhitungan \\
\hline 3. & File & Varchar (50) & File untuk mengetahui file dari perhitungan fisik \\
\hline 5. & Date_Created & Int (11) & Date Created untuk mengetahui tanggal cetak atau pembuatan \\
\hline
\end{tabular}

Untuk relasi desain tabel perhitungan hasil, dapat disederhanakan dengan self relation, yang dapat terlihat pada tabel 11.

TABEL 11

TABel Perhitungan Hasil

\begin{tabular}{llll}
\hline No & Nama & Type & Keterangan \\
\hline 1. & Id_Perhitungan_Hasil & Int (11) & ID Perhitungan Hasil sebagai primary key \\
\hline
\end{tabular}




\begin{tabular}{llll}
\hline No & Nama & Type & Keterangan \\
\hline 2. & Id_Perhitungan_Fisik & Int (11) & ID PerhitunganFisik sebagai primary key \\
\hline 3. & Id_Jenis_Barang & Int (11) & Id Jenis Barang sebagai primary key \\
\hline 4. & Stok_Sistem & Int (11) & Stok sistem untuk mengetahui stok yang ada di sistem \\
\hline $\mathbf{5 .}$ & Jumlah_Perhitungan_Fisik & Int (11) & Jumlah perhitungan Fisik untuk mengetahui ada berapa yang terhitung Fisik \\
\hline
\end{tabular}

\section{H. Tampilan Website}

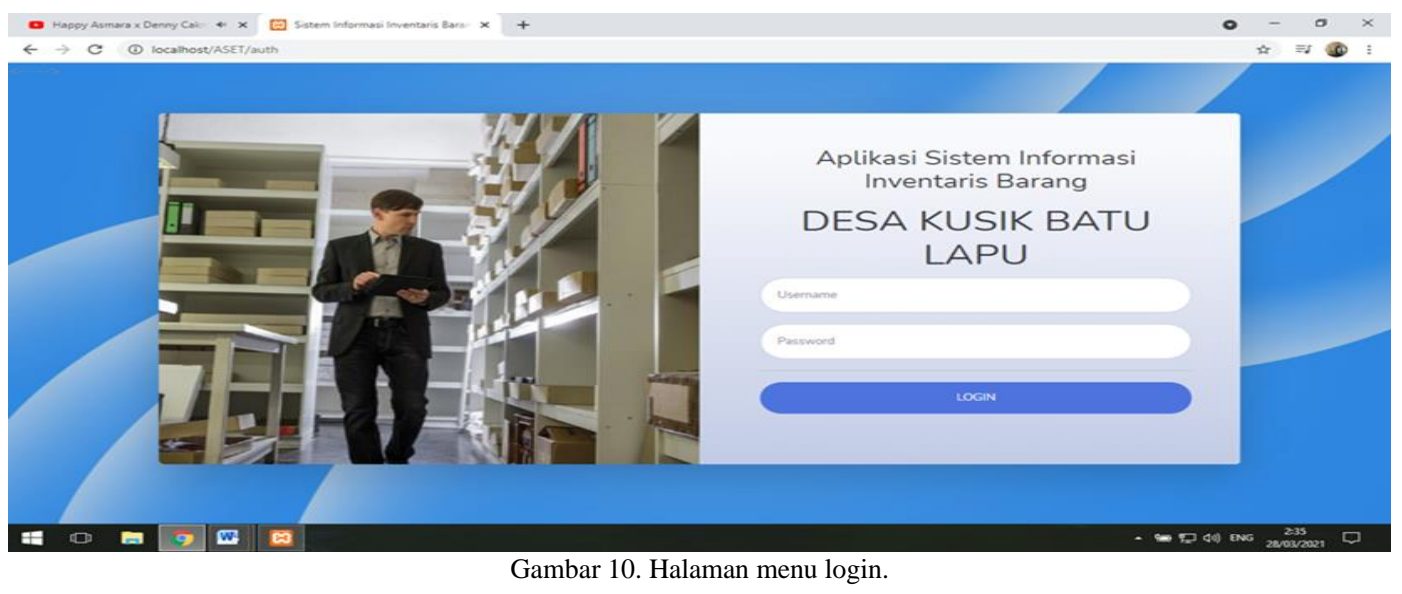

Pada Gambar 10. ditampilkan halaman menu login ini dapat digunakan untuk Bendahara saja. Bendahara login dengan username dan password yang sudah diberikan. Cara menggunakan aplikasi sistem ini dengan memasukkan username dan password yang tersedia. Klik tombol "LOGIN" maka user akan beralih ke halaman selanjutnya (Dashboard).

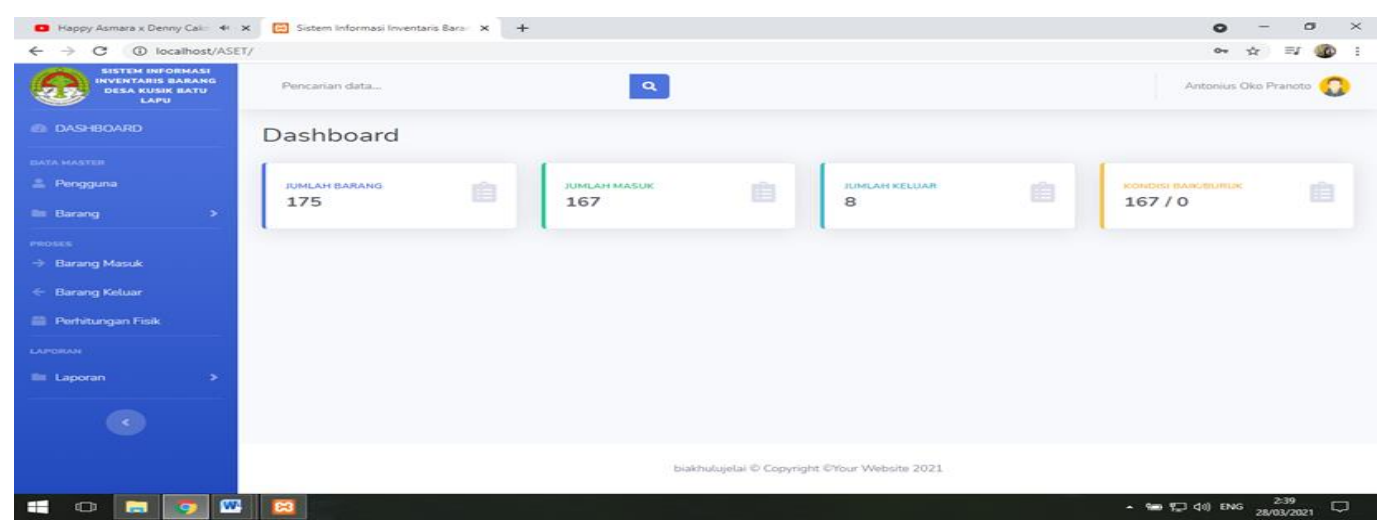

Gambar 11. Halaman utama/dashboard.

Pada Gambar 11. ditampilkan halaman utama atau dashboard untuk melihat menu yang terdapat didalam aplikasi.

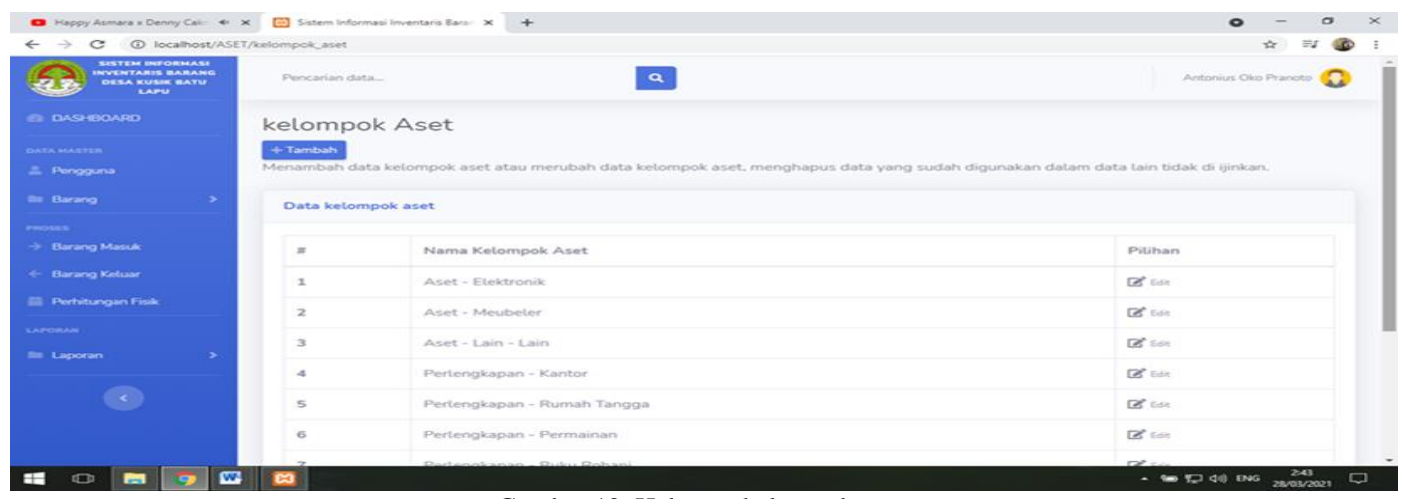

Gambar 12. Halaman kelompok aset. 
Pada Gambar 12. ditampilkan halaman kelompok aset untuk menginput kelompok data barang. Cara menggunakannya, bendahara memasukkan data yang jelas sesuai kolom yang tersedia mulai dari no dan nama kelompok aset. Setelah kolom terisi semua dapat menekan tombol "Simpan" dengan begitu data sudah tersimpan di sistem. Jika ada perubahan bendahara dapat mengklik "Edit".

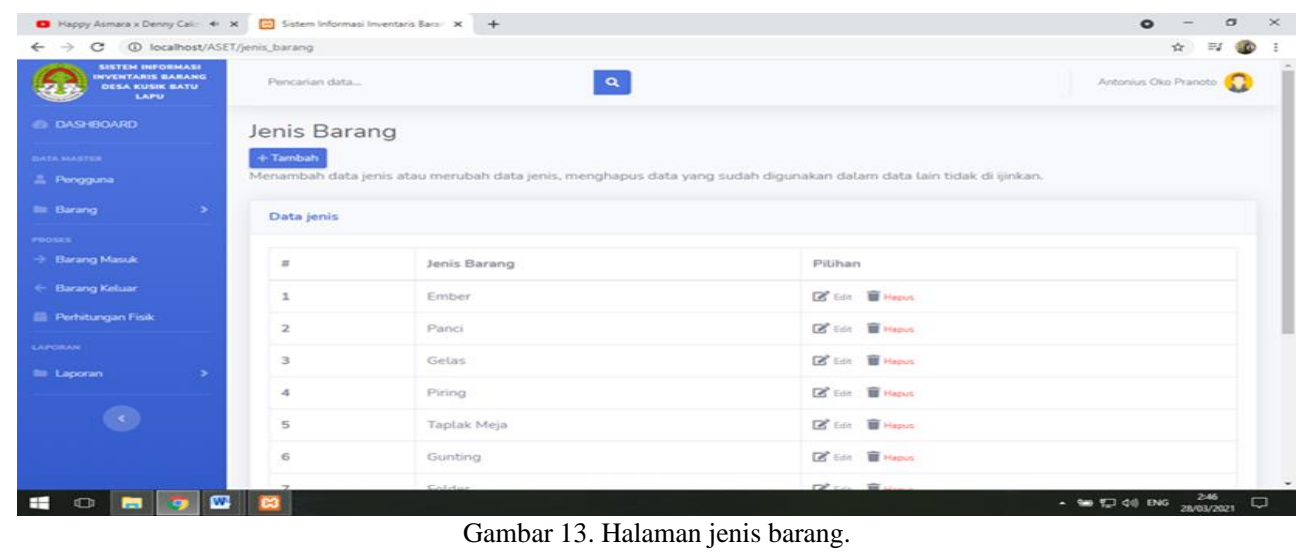

Pada Gambar 13. ditampilkan halaman jenis barang digunakan untuk melakukan Penginputan jenis barang. Dimana terdapat kolom no, jenis barang dan pilihan.

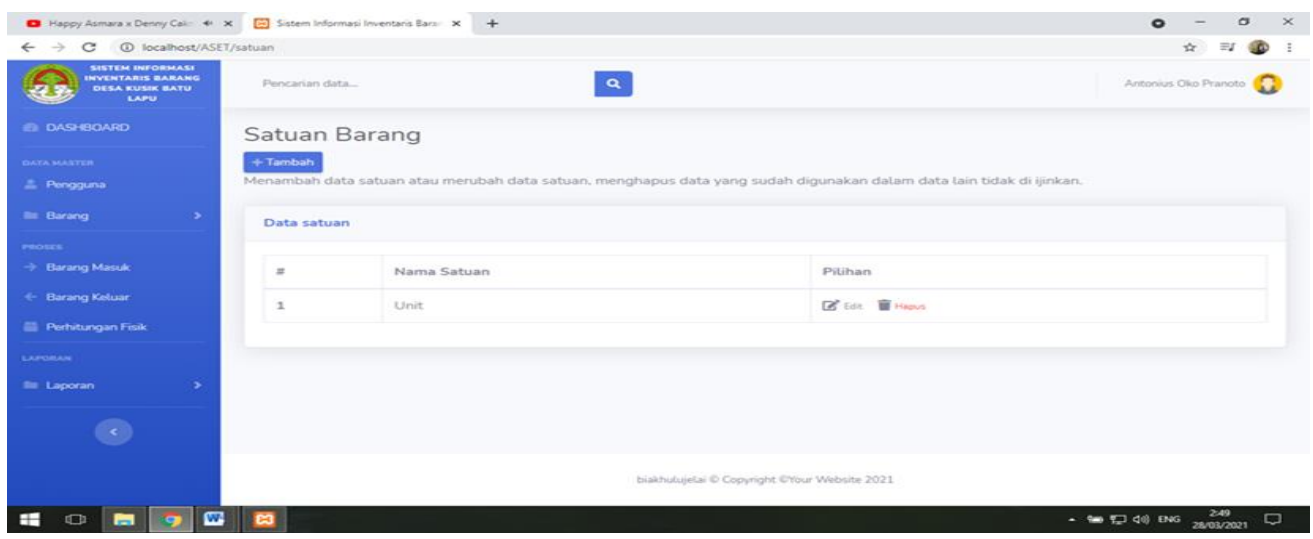

Gambar 14. Halaman satuan barang.

Pada Gambar 14. ditampilkan halaman satuan barang digunakan untuk melakukan penginputan pada item. Dimana terdapat nama satuan dan pilihan.

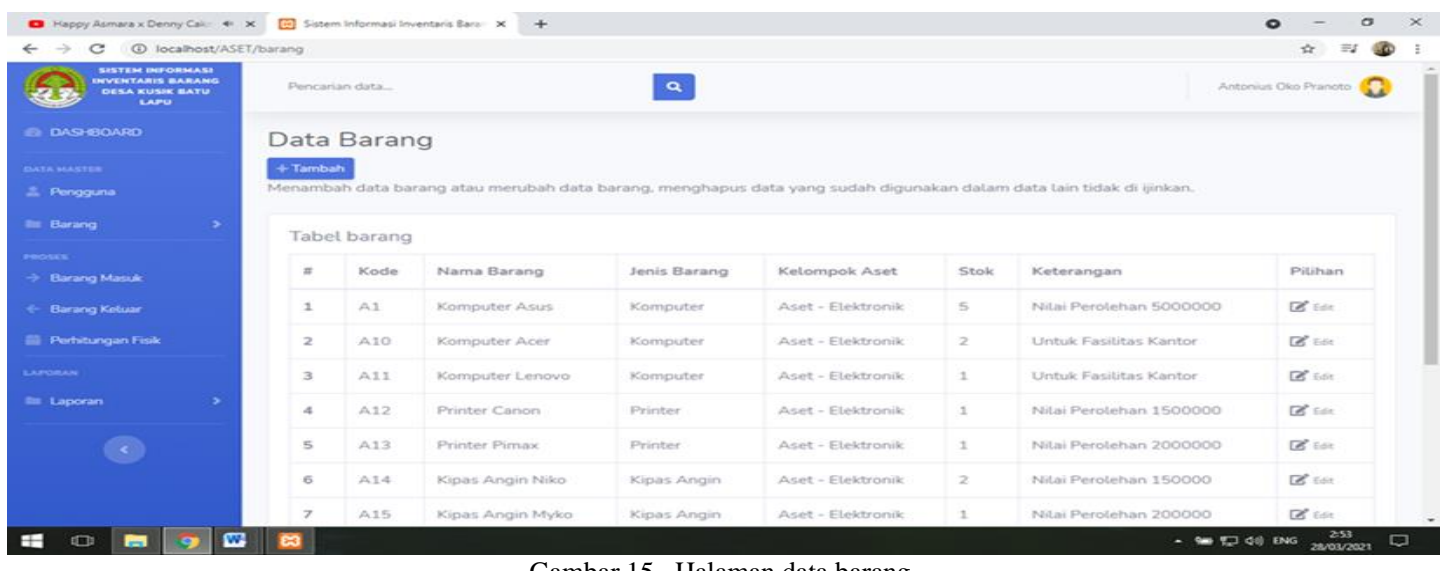

Gambar 15. Halaman data barang. 
Pada Gambar 15. ditampilkan halaman data barang digunakan untuk melakukan penginputan data barang. Dimana terdapat kolom no, kode barang, jenis barang, kelompok aset, stok dan pilihan.

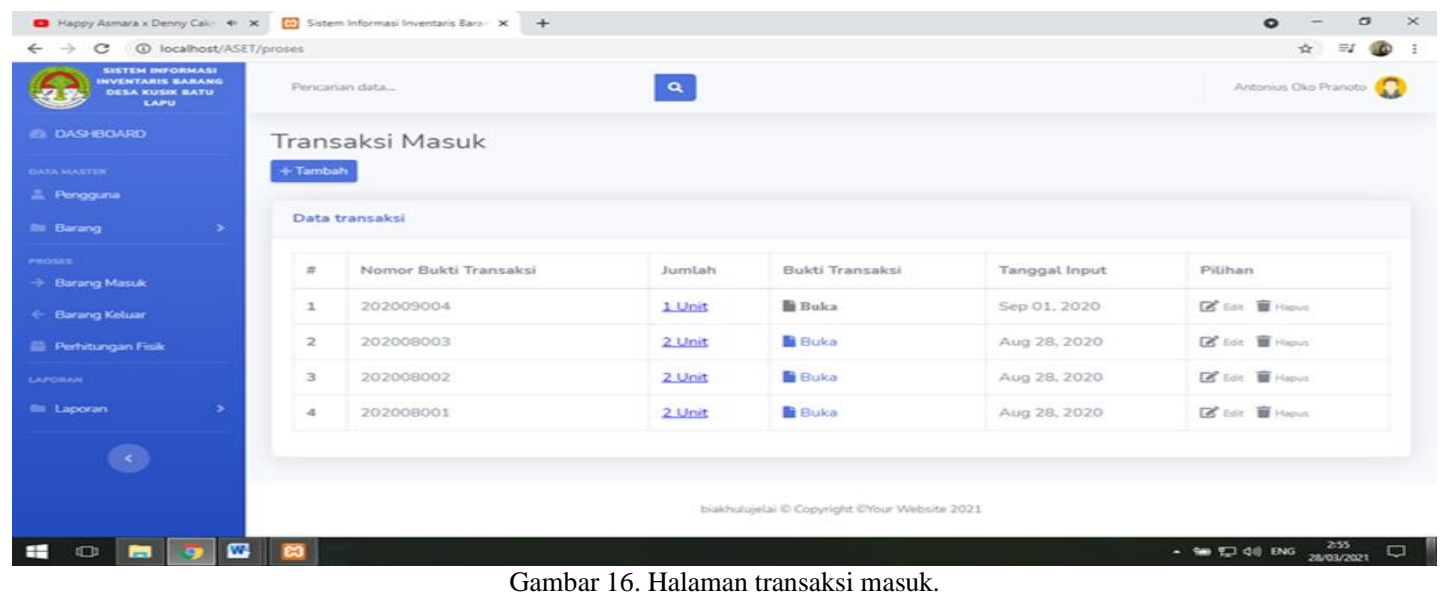

Pada Gambar 16. ditampilkan halaman transaksi masuk digunakan untuk menampilkan data- data barang dimana terdapat kolom no, no transaksi, jumlah, bukti transaksi, tanggal input, dan pilihan.

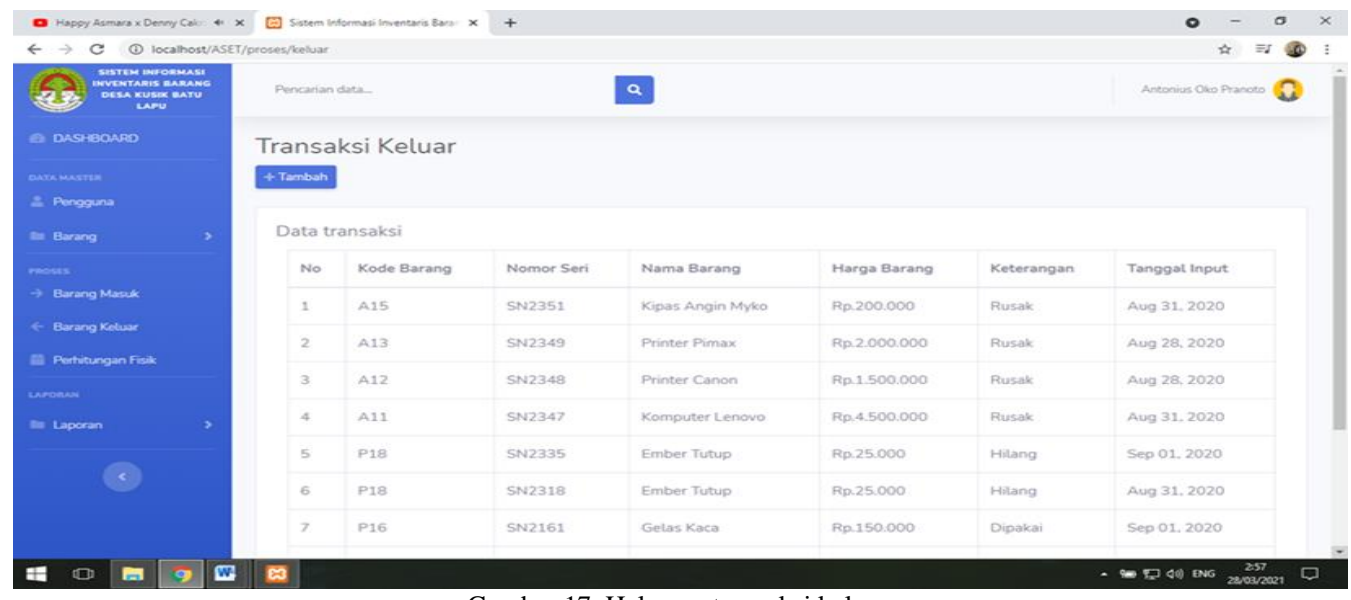

Gambar 17. Halaman transaksi keluar.

Pada Gambar 17. ditampilkan halaman transaksi keluar digunakan untuk menampilkan data- data barang keluar dimana terdapat kolom no, kode barang, nomor seri, nama barang, harga barang, keterangan, tanggal input.

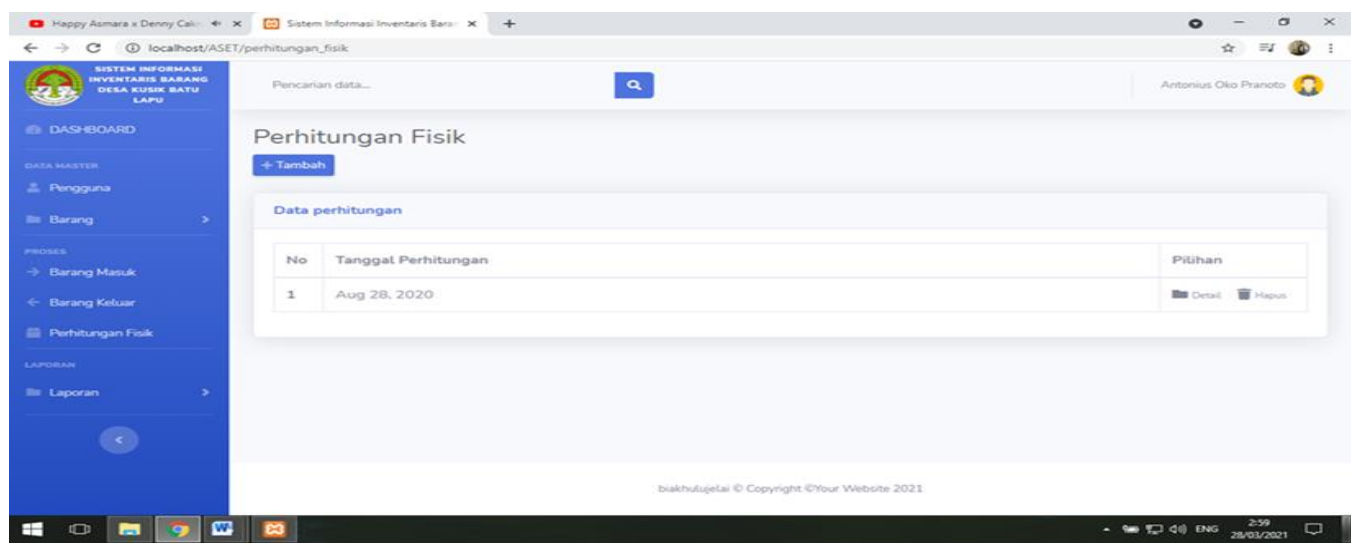

Gambar 18. Halaman perhitungan fisik. 
Pada Gambar 18. ditampilkan halaman perhitungan fisik digunakan untuk mengetahui data barang fisik dimana terdapat kolom no, tanggal perhitungan dan pilihan.

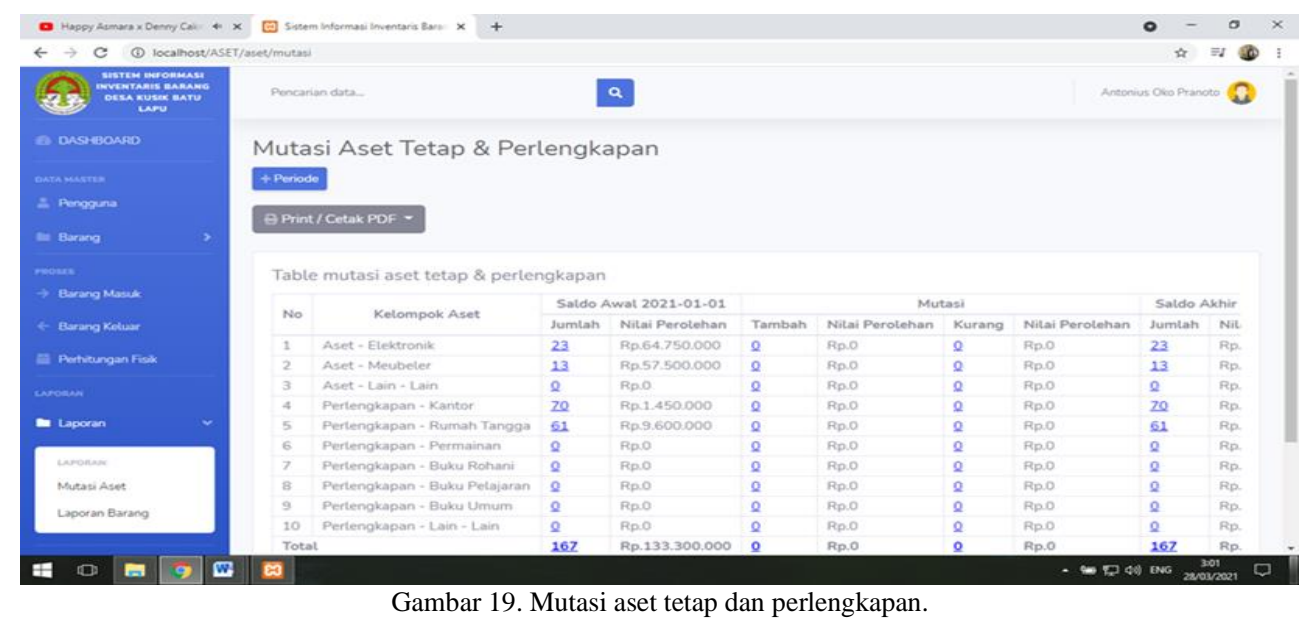

Pada Gambar 19. ditampilkan halaman mutasi aset tetap dan Perlengkapan digunakan untuk mengetahui nilai bertambah atau berkurangnya saldo awal dan saldo akhir.

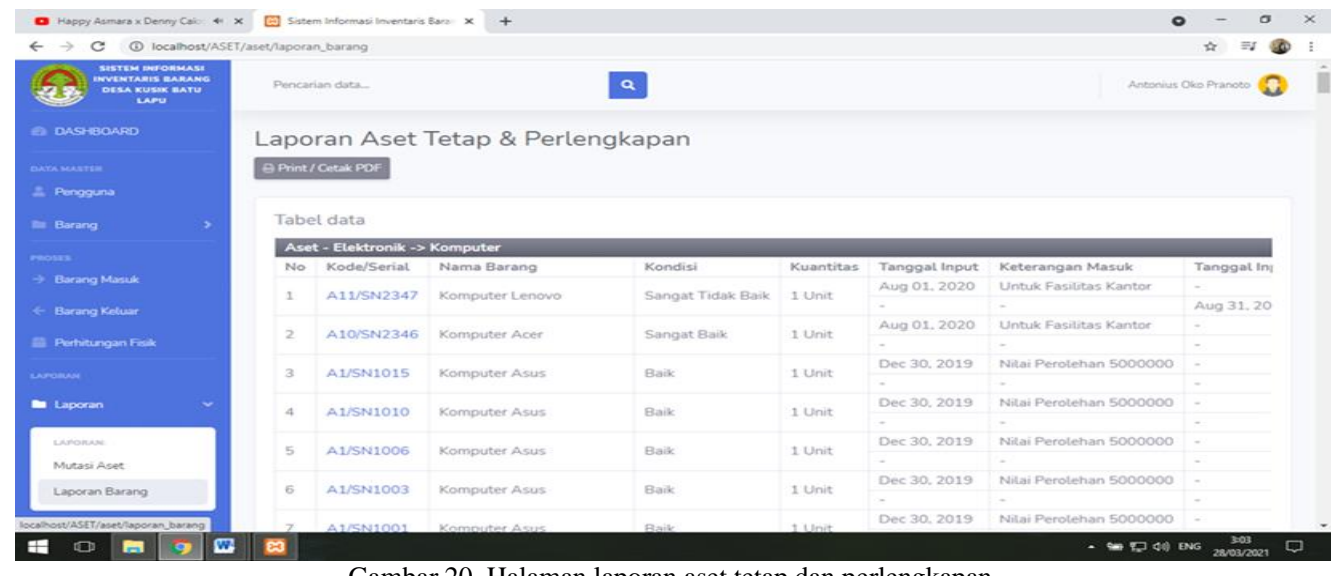

Gambar 20. Halaman laporan aset tetap dan perlengkapan.

Pada Gambar 20. ditampilkan halaman laporan aset tetap dan perlengkapan digunakan untuk menginput dari data-data transaksi. Dimana terdapat no, kode barang, nama barang, kondisi, tanggal input, keterangan masuk, tanggal input, dan keterangan keluar.

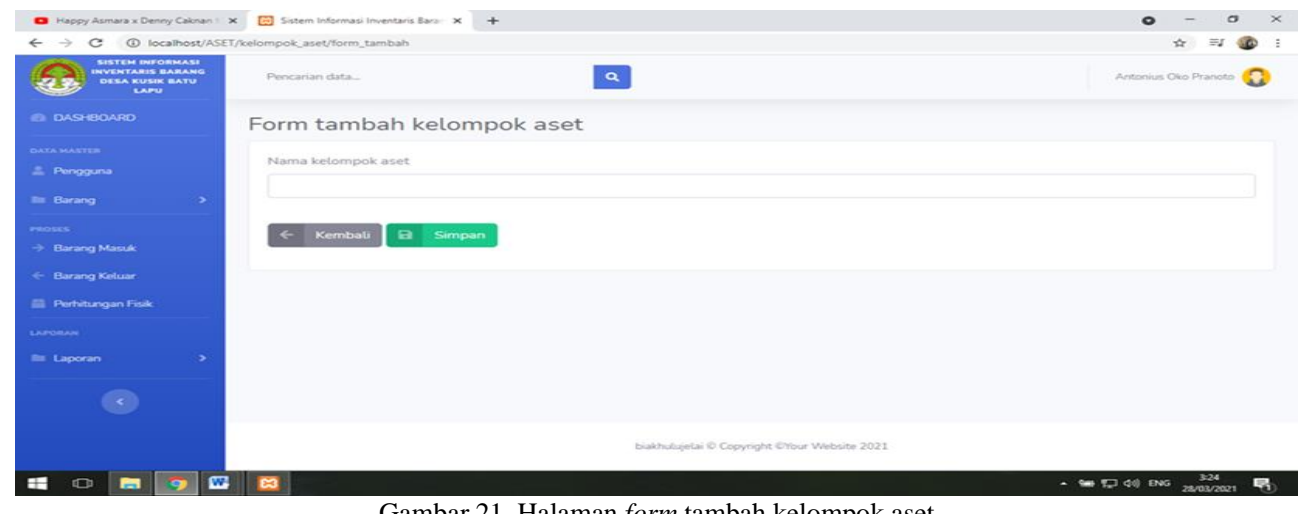

Gambar 21. Halaman form tambah kelompok aset

Pada Gambar 21. ditampilkan tampilan form untuk menambah kelompok aset. 


\section{SIMPULAN}

Penelitian ini menghasilkan sebuah sistem informasi inventaris barang di Desa Kusik Batu Lapu, Kalimantan Barat. Dengan sistem yang sudah terkomputerisasi akan membuat lebih memudahkan pengguna dalam mengelola data inventaris barang sehingga membuat pekerjaan menjadi lebih efektif dan efisien, dimana sistem yang dibuat dapat melakukan proses pencarian data barang masuk dan barang keluar, serta dapat membuat laporan data barang inventaris secara cepat dan akurat sehingga tidak akan terjadi lagi duplikasi data. Diharapkan dengan adanya sistem informasi inventaris barang dapat mempercepat dan mempermudah pelayanan di Kantor Desa Kusik Batu Lapu, Kalimantan Barat. Menu atau fitur yang terdapat didalam tampilan aplikasi sistem informasi inventaris barang yaitu data pengguna, data barang, jenis barang, satuan barang, kelompok barang, barang tambah/masuk, barang kurang/keluar, perhitungan fisik, dan laporan [3].

Dari berbagai analisa dan pengamatan yang dilakukan dalam proses implementasi program mengenai sistem informasi inventaris barang di Desa Kusik Batu Lapu, Kalimantan Barat, maka saran-saran yang akan disampaikan sebagai berikut : sistem informasi belum memasukkan perhitungan penyusutan aset tetap, dan peneliti selanjutnya bisa meneruskan untuk merancang aplikasi sistem informasi perhitungan penyusutan aset tetap [4].

\section{UCAPAN TERIMA KASIH}

Ucapan terima kasih disampaikan kepada FTI UKSW, Direktorat Riset Dan Pengabdian Masyarakat, dan LLDIKTI Wilayah VI karena fasilitas yang diberikan untuk publikasi ini. Kontrak Nomor: 237/SP2H/LT/DRPM/2021 Tanggal 18 Maret 2021.

\section{DAFTAR PUSTAKA}

[1] Sudarsono, Nono \& Sukardi. 2015. "Sistem Informasi Inventory Berbasis Web di PT. Autotech Indonesia". Jurnal Eksplora Informatika Vol. 5 No. 1 September 2015, hal. 73-84

[2] Veza, Okta \& Ropianto, M. 2017. "Perancangan Sistem Informasi Inventory Data Barang pada PT. Andalas Berlian Motors". Jurnal Teknik Ibnu Sina (JT-IBSI) Vol. 2 No. 2 Oktober 2017, ISSN: 2541- 2647.

[3] Rakhel, Yuniati dkk. 2016. "Perancangan Sistem Informasi Inventaris berbasis mobile (Studi Kasus: STMIK Provisi Semarang)". Jurnal KOMPUTAKI Vol. 1 No. 1 Februari 2016, hal. 132-145

[4] Syukri Ali., Arisandy Ambarita. 2016. "Sistem Informasi Data Barang Inventaris Berbasis Web Pada Kejaksaan Negeri Ternate". Jurnal Indonesian Journal on Information System (IJIS) Vol. 1 No. 1 April 2016, hal.31-38

[5] Nastiti, F. E., \& Kusumawati, N. 2014. Sistem Informasi Inventarisasi Sarana dan Prasarana Sekolah (STUDI KASUS: Madrasah Tsanawiyah Muhammadiyah Surakarta). Jurnal Sistem Komputer, 4(2), 43-48.

[6] Purwanto, Radika. 2011. Sistem Perancangan Data Inventaris Kantor IMS (Indocement Maintenance System) pada PT Indocement Tunggal Perkasa Tbk, Naskah Publikasi. Jurusan Teknik Informatika Sekolah Tinggi Manajemen Informatika Dan Komputer Amikom, Yogyakarta.

[7] Juliani, Eva. 2017. "Sistem Informasi Sarana Dan Aset Di Universitas Teknologi Sumbawa” Skripsi Program Studi Informatika Fakultas Teknik Universitas Komputer Teknologi Sumbawa.

[8] Syakir, Imam B. 2011. "Sistem Inventarisasi Barang di Technical Departement IT Metro TV"

[9] http://www.google.com/"jurnal perencanaan inventarisasi peralatan kantor dengan aplikasi microsoft access". (10 Oktober 2018).

[10] Purwanto, Radika,2011, Sistem Perancangan Data Inventaris Kantor IMS (Indocement Maintenance System) pada PT Indocement Tunggal

[11] Agus Satriansyah. 2018. "Sistem Informasi Inventaris Alat Tulis Kantor Dan Suvenir Pada Kantor Pelayanan Pajak Pratama Sumbawa Sumbawa Besar Berbasis Dekstop”. Skripsi Program Studi Informatika Fakultas Teknik Universitas Komputer Teknologi Sumbawa.

[12] Rohayati, R., \& Irwandi, A. 2016. Perancangan Dan Implementasi Sistem Informasi Inventaris Laboratorium. INTEKNA, 16(2), 115-119. 